\title{
DE WEST EN ONZE SCHEEPVAART ${ }^{1}$ )
}

\author{
DOOR
}

W. R. MENKMAN

Het gedeelte van de nieuwe wereld dat in de $15 \mathrm{e}$ en $16 \mathrm{e}$ eeuw voor de Spaansche kroon werd veroverd, of in bezit genomen, heeft bij de Spanjaarden den naam behouden van „las Indias”, ook nadat was komen vast te staan dat het gebied in kwestie met Indië niet den minsten samenhang heeft; en zoo zijn ook Engelschen en Nederlanders den naam Indië blijven verbinden aan hunne nederzettingen in tropisch Amerika.

Met dien verstande dan dat de Engelschen met de West-Indies alleen bedoelen de Britsch-Westindische eilanden en hunne koloniën op het vasteland van Centraal- en Zuid-Amerika afzonderlijk noemen, terwijl voor ons Nederlanders West-Indië de verzamelnaam is voor het geheele Nederlandsche gebied in Amerika.

Misschien is dit laatste niet heelemaal juist; het schijnt dat de meeste Hollanders, wanneer zij spreken van de West, of van WestIndië, uitsluitend, of in de eerste plaats, denken aan Suriname en dat het pas tot hen doordringt dat wij, behalve dit vastelandsgebied in Zuid Amerika, ook nog een zestal eilanden bezitten in de Caraïbische Zee, wanneer zij door een of andere bijzondere gebeurtenis speciaal daaraan worden herinnerd.

En dan moet men zich nog afvragen aan hoevele courantenlezers h. t. l. de situatie direct duidelijk zal zijn geweest, toen verleden jaar daar op Curaçao die schokkende gebeurtenis had plaats gehad, welke voor korten tijd de aandacht van het groote publiek hier in Holland weder eens concentreerde op onze West.

Het moet zelfs zijn voorgekomen, dat men zich ongerust maakte over het lot van verwanten in de West, hoewel die verwanten gevestigd waren in het rustige Paramaribo, waar nooit Ve-

1) Voordracht met lichtbeelden op 11 Febr. 1930 te Amsterdam gehouden (5e lezing van den Economisch-Historischen Leergang „WestIndië in Verleden en Heden"'). 
nezolanen komen, waar men nooit met de Venezolaansche politiek te maken heeft en dat bovendien bijna 2000 K.M. verwijderd ligt van het terrein van Urbina's overval.

Voor ons Europeanen vangt de geschiedenis van Amerika en voor ons Nederlanders vangt dus in zekeren zin de geschiedenis van de West aan, met het oogenblik van Columbus' aankomst op het eilandje dat de Spanjaarden San Salvador doopten en dat thans Engelsch is en Watling Island heet.

In verband hiermede moge er even aan worden herinnerd dat tot de landen welke door Columbus zijn ontdekt ook behoort de eilandengroep waarvan onze tegenwoordige Bovenwindsche Eilanden deel uitmaken, niet echter Suriname en onze Benedenwindsche eilanden; deze laatste twee gebieden werden door tijdgenooten van den grooten zeevaarder ontdekt, respectievelijk het eerst gezien of het eerst vermeld.

Geenszins zijn oorsponkelijke doel, door naar het Westen te varen de Oostelijke kusten van Azië te bereiken, uit het oog verliezende, zette Columbus op zijn vierde en laatste reis (1502) naar de smalle landengte koers tusschen Centraal- en Zuid-Amerika, hopende via Darién de specerij eilanden - de Molukken dus - te kunnen bezeilen, van waar juist de eerste Portugeesche vloot rijkbeladen was thuis gevaren; hij vond echter tot zijn teleurstelling geen doortocht voor schepen en het probleem der interoceanische verbinding was ontstaan. slechts weinige jaren na de ontdekking der nieuwe wereld.

Tot een kunstmatigen waterweg, daar waar Columbus tevergeefs een natuurlijke doorvaart zocht, is het nimmer gekomen en evenmin als de kust van Darién is de Golf van Mexico uitgangspunt geworden van een scheepvaartverbinding van zee tot zee. De landengte van Tehuantepec immers wordt tegenwoordig wel doorsneden door een spoorweg van Puerto Mexico naar Salina Cruz, maar de doorgraving is een theoretische mogelijkheid gebleven.

Tusschen deze beide uitersten evenwel werden twee andere mogelijkheden geboden om de scheepvaart een weg te openen naar de andere zijde, waarvan er, zooals bekend is, één is benut geworden voor het aanleggen van een kanaal, dat van Panamá, geopend vier eeuwen na den tijd van Columbus en Balboa; in 1855 echter was de oude Spaansche overlandverbinding reeds vervangen door een spoorweg.

Komt er ooit een tweede kanaal tot stand, en het is zeer waarschijnlijk dat dit binnen afzienbaren tijd zal geschieden, dan zal 
de Nicaragua-route worden gevolgd en dan zal de onderneming wederom een Amerikaansche zijn, evenals de doorgraving der landengte van Panamá. De belangstelling der Vereenigde Staten voor de republiek Nicaragua, ook op politiek terrein, staat natuurlijk met het kanaalplan in nauw verband.

Het Nicaragua-project heeft het aantrekkelijke dat er voor de uitvoering gebruik zal kunnen worden gemaakt van een rivier en van een meer en dat reeds de Spanjaarden oog hadden voor dit voordeel blijkt wel hieruit, dat zij reeds in de 16e eeuw de San Juan rivier en het meer van Nicaragua hebben geëxploreerd, met het oog op een interoceanische scheepvaartverbinding.

Een Nicaragua-kanaal werd druk besproken in het begin der $19 \mathrm{e}$ eeuw, ook in ons land, waar Koning Willem I er zich zeer voor interesseerde; hij zag er n.l. een middel in ter bevordering van de Nederlandsch-Westindische belangen.

Het zwaartepunt van die belangen, op algemeen eoconomisch en op scheepvaartgebied, ligt ook thans in de Caraïbische Zee, zij het dan ook door omstandigheden welke honderd jaar geleden niet alleen nog niet aanwezig waren, maar destijds zelfs niet konden worden voorgevoeld.

Dat het eiland Curaçao snel is opgekomen, als nijverheids- en scheepvaartcentrum, terwijl het continentale Suriname, eertijds een rijke plantage-kolonie, maar niet tot welvaart kan geraken, is een verschijnsel, teekenend voor den nieuwen tijd en vooral voor de nieuwe wereld; snelle opkomst van industrie en verkeer en daar tegenover een min gunstige conjunctuur op landbouwegbied.

Het ligt voor de hand dat Suriname, gelegen buiten de Caraïbische Zee en buiten de routes naar oeconomisch meer belangrijke landen, zonder achterland en zonder natuurlijke havens voor diepgaande schepen, slechts zooveel scheepvaartverkeer heeft als de eigen - thans nog beperkte- behoeften vereischen; onze eilanden daarentegen liggen in een zeer druk bevaren binnenzee en bezitten verschillende natuurlijke havens van aanzienlijke capaciteit.

Die eilanden, of de Nederlandsche Antillen, vormen tezamen wat, volgens de constitutioneele indeeling van het Koninkrijk der Nederlanden, als gebiedsdeel „Curaçao" heet, doch zij bestaan uit twee in menig opzicht zeer verschillende en ook zeer ver uit elkander liggende groepen; zoodat Nederlandsch West-Indië kan worden beschouwd als te zijn samengesteld uit drie deelen, Suriname, de Benedenwindsche en de Bovenwindsche eilanden, onderlinge afstanden respectievelijk circa 1800 , circa 900 en ruim 1800 K.M. 
Bepalen wij ons, ten aanzien van de internationale verhoudingen, tot de Caraïbische Zee, waarin onze Nederlandsche Antillen zijn gelegen en waar niet minder dan vijftien verschillende vlaggen waaien, dan treft direct de machtige positie van de Vereenigde Staten, door de souvereiniteit over de Panamá Kanaal Zone, maar niet daardoor alleen.

Cuba, de grootste der Antillen, is sedert kort na den SpaanschAmerikaanschen oorlog een zelfstandige staat, maar sterk Noordamerikaansch beïnvloed; de ligging alleen reeds verklaart dit voor een deel. De hoofdstad Havana ligt slechts circa 175 K.M. verwijderd van Key West, de Zuidelijkste stad en tevens het Zuidelijkste spoorwegeindpunt der Vereenigde Staten, gelegen op een der tot den staat Florida behoorende en onderling tot een keten verbonden kleine eilandjes, de Keys, van het Spaansche cayo of klip. Het uitgebreide Cubaansche spoorwegnet sluit daardoor aan bij dat der Vereenigde Staten, met als schakel den veerbootdienst Havana-Key West, ingericht op den overvoer van spoorwagens tusschen deze beide punten.

De oeconomische en finantiëele betrekkingen tusschen de beide landen zijn belangrijk en talrijk; de preferentie welke de Cubaansche suiker in de Vereenigde Staten geniet op het punt van invoerrecht is er één van. En wat de strategische positie betreft, Cuba verleent gastvrijheid aan de Vereenigde Staten voor een marine-station aan de Zuidoostkust van het eiland, in de schoone baai van Guantánamo, dicht bij de Windward Channel.

De volgende in de rij der groote Antillen is het oude Hispañola van Columbus, thans verdeeld in de republieken Haïti en Santo Domingo, beide feitelijk protectoraten der Vereenigde Staten. Haïti heeft zelfs een Amerikaansche bezetting, Santo Domingo niet meer, maar de Dominikaansche geldmiddelen worden nog door de Vereenigde Staten gecontroleerd; voor de oeconomische ontwikkeling vestigt men zijn hoop op de hulp van de groote Noordamerikaansche republiek, door een preferentieel suikertarief en in andere vormen.

Dan volgt Porto Rico, sedert 1898 grondgebied van de Vereenigde Staten, en dan nog Oostelijker St. Thomas en twee andere kleine eilanden, vroeger Deensch koloniaal gebied en in 1916 aan de Vereenigde Staten afgestaan; St. Thomas met zijn mooie haven is ook alweder een Amerikaansch marine-station.

Vier voorname toegangen tot de Caraïbische Zee, en wel de vier die het belangrijkst zijn voor de verbinding met het Noorden, worden dus door de Vereenigde Staten beheerscht, t. w. Straat 
Florida, de Windward Channel, de Mona Passage en de doorgang ten Oosten van Porto Rico, bij St. Thomas.

De 65e lengtegraad vormt ongeveer de scheidingslijn, d. w. z. in den kwartcirkel die het meest naar Europa is toegewend vinden wij alleen doorgangen welke nog altijd door Engeland en Frankrijk worden gecontroleerd.

De eilanden in dien kwartcilkel zijn voor de Spaansch sprekenden ,islas de barlovento", eilanden dus van de wind- of loefzijde, omdat, van af het vasteland redeneerende, die eilanden dáár liggen waar de wind van daan komt. En met den wind wordt dan natuurlijk bedoeld de N.O. passaat, welke in deze streken bijna constant waait, aan de landen der Caraïbische Zee hun gezegend klimaat verleent en vroeger van zoo groot belang was voor de scheepvaart.

De Engelschen verdeelen die eilanden in windward islands en leeward islands, met de grensscheiding bij Dominica, een verdeeling berustende op de kracht van den wind; de Zuidelijke of Windwards ondervinden meer den invloed van den passaat dan de Noordelijke of Leewards.

Ook onze onderscheiding Bovenwindsche en Benedenwindsche eilanden houdt natuurlijk verband met den N.O. passaat. Ten opzichte van de eilanden onder de Noordkust van Zuid-Amerika liggen Sint Maarten, Sint Eustatius en Saba boven den wind en als tegenstelling zijn dan Curaçao, Aruba en Bonaire benedenwinds.

Wat van die laatste, vooral van Curaçao, de waarde voor de scheepvaart verhoogt, is de veiligheid; immers onze benedenwindsche eilanden liggen buiten het gebied der Westindische orkanen of hurricanes, waarvan onze benedenwindsche wèl af en toe den invloed ondervinden, evenals St. Thomas.

Alle belangrijke scheepvaartroutes naar en door de Caraibische Zee worden tegenwoordig door Nederlandsche schepen bevaren en het geheele complex van Nederlandsche lijnen vormt een netwerk waarvan de draden alle plaatsen in dat zeegebied raken welke voor handel en verkeer van beteekenis zijn.

Die Nederlandsche lijnen vinden hun eindpunten in de Caraïbische Zee zelf, in New York (die naar het Noorden), in de Golf van Mexico (die naar het Westen), of aan de Westkusten van Noorden van Zuid-Amerika (in de twee laatste gevallen natuurlijk via het kanaal van Panamá).

Van die lijnen, in de scheepvaartwereld onder verschillende namen bekend, moge hier afzonderlijk worden vermeld de Suriname- 
lijn, d.i. die van Amsterdam naar Paramaribo, verder langs de kust naar Curaçao en dan via Haïti naar New York, als zijnde dit de pionierlijn, de eerste Nederlandsche stoomvaartlijn op de West.

Op twee na zijn alle Nederlandsch-Westindische lijnen Amsterdamsche lijnen, bevaren door schepen van de Kon. Ned. Stoomboot Maatschappij. De twee uitgezonderde zijn Rotterdamsche, bevaren door schepen van de Ned. Amerik. Stoomvaart Maatschappij, t.w. die via Havana naar de Golf van Mexico (Vera Cruz en Tampico) en die via Jamaica - of via Curaçao - door het Panamá-kanaal naar de Westkust van Noord-Amerika (Los Angeles, San Francisco, Vancouver en Seattle).

Van groot belang is de centrale positie van Curaçao, waar zoovele Nederlandsche lijnen tezamen komen niet alleen, maar dat bovendien aanloophaven is van een aantal groote buitenlandsche lijnen, behoorende tot een zestal verschillende naties.

In 1928 bedroeg de tonnage der op Curaçao binnengeloopen schepen ruim anderhalf maal zooveel als die van de Amsterdamsche zeescheepvaart en Curaçao is dan ook na Rotterdam de drukste zeehaven van het Koninkrijk der Nederlanden.

Die toestand echter is eerst in den allerlaatsten tijd ontstaan; nog maar twintig jaar geleden was er op Suriname, dat nu in dit opzicht zoo misdeeld lijkt, meer groote scheepvaart onder Nederlandsche vlag dan op Curaçao, waar men destijds meer Duitsche en meer Amerikaansche stoomschepen zag dan Nederlandsche.

Dat was n.l. in den tijd toen onder onze nationale vlag een wekelijksche dienst werd onderhouden tusschen Paramaribo en New York, ten behoeve van de bacovecultuur in Suriname, onder overeenkomst met de United Fruit Company.

Deze zeer belangrijke Amerikaansche onderneming heeft het allergrootste aandeel gehad in de ontwikkeling der cultuur van vruchten voor export in verschen toestand - in de eerste plaats bananen - in West-Indië, Centraal- en Zuid-Amerika; ed scheepvaartlijnen noodig voor het vervoer dier vruchten, naar de Vereenigde Staten en naar Europa, vormen een ander uitgebreid netwerk op de kaart van Caraïbische Zee en Golf van Mexico; de Surinaamsche vruchtenlijn was destijds de eenige buiten dat net vallende.

Toen de bacove-cultuur mislukt werd geacht, verviel automatisch deze snelle verbinding tusschen Nederlandsch Guiana en de Vereenigde Staten en werd aan groote verwachtingen van Suriname als vruchtenexporteerend land de bodem ingeslagen. 
Een voor onze betrekkingen met de West zeer belangrijk land is de republiek Venezuela, een der weinige landen welke geen kuststrook hebben buiten de Caraïbische Zee en die dus voor het verkeer met Europa en met Noord-Amerika - en dat staat voor Venezuela vrijwel gelijk met het verkeer met de buitenwereld - geheel van de toegankelijkheid dezer binnenzee afhankelijk zijn.

En bovendien verkeert Venezuela nog in de bijzondere omstandigheid dat alleen het middengedeelte van haar kustlijn havenaccommodatie aanbiedt voor het groote scheepvaartverkeer (Laguaira, voorhaven van de hoofdstad Caracas) en het Oostelijk gedeelte - het Orinoco gebied, met de stad Bolivar - alsmede het Westelijk gedeelte - het gebied van het meer van Maracaibo, met de stad van dien zelfden naam - daarvan verstoken zijn, als gevolg van de natuurlijke gesteldheid.

De monden van de Orinoco - een delta - leveren een nog iets minder gunstige gelegenheid op dan onze Surinaamsche rivieren en met het meer van Maracaibo is het nog slechter gesteld. De nauwe en ondiepe hals, welke tot het meer toegang geeft, is alleen voor kleine schepen - of wat wij tegenwoordig kleine schepen noemen - bevaarbaar.

Als voorhaven voor het Orinoco-gebied dient het Engelsche eiland Trinidad en het Maracaibo-gebied is aangewezen op de Nederlandsche Benedenwindsche eilanden, vooral op Curaçao, dat betere natuurlijke havens heeft dan het iets dichterbij gelegen Aruba.

En waar het Maracaibo-gebied veel belangrijker is dan het Orinoco-gebied, is het maar goed dat van die eilanden onder Venezuela's kust welke aan de beide uiteinden als natuurlijke voorhavens dienen, juist de Westelijke Nederlandsch zijn, goed niet alleen voor ons, maar ook voor Venezuela zelf,

Men kan zich Curaçao denken als een pistool op de borst van Venezuela, of althans op een belangrijk deel van Venezuela, en hoewel verleden jaar dat pistool even is afgegaan, zij het door onze nalatigheid, maar zeker niet met onzen wil, zal Venezuela zich toch in het algemeen wel gelukkig achten dat het in handen is van het kleine en vredelievende Nederland en niet van een machtiger maritieme en militaire mogendheid.

Waarom juist dat Maracaibo-gebied zoo belangrijk is?

De stad Maracaibo is na de hoofdstad de grootste des lands, uitvoerhaven van koffie, niet alleen uit Venezuela zelf, maar ook uit het naburige Columbia, vooral van die uit Cucutá.

Bovenal echter wegens den rijkdom aan aardolie rondom het meer, dat echter voor groote schepen niet toegankelijk is. 
Het ruwe product wordt nu met kleine tankschepen vervoerd naar onze Benedenwindsche eilanden, waar de raffinage plaats heeft en waar de voor de oceaanvaart gebouwde groote tankers goede havens vinden.

Op deze wijze is het voor de olieindustrie uiterst gewichtige vervoerprobleem op de beste wijze opgelost kunnen worden en bovendien was het voor de Europeesche en Amerikaansche belanghebbenden maar veiliger de kostbare installaties te vestigen op de Nederlandsche eilanden en niet in Venezuela zelf.

En ten slotte is de situatie, vooral van Curaçao uiterst gunstig voor den afzet van vloeibare brandstoffen aan oliestokende stoomschepen en aan motorschepen.

Curaçao, dat in zoo hooge mate profiteert van de olie-industrie, is dus omgekeerd van zeer groote waarde voor die industrie.

Onze nationale scheepvaart op de West, thans omvangrijker dan ooit te voren, is al van zeer ouden datum; al hebben onze voorouders geen deel gehad in de ontdekking van Amerika, hun schepen en hun schippers wisten reeds vrij vroeg in de $16 \mathrm{e}$ eeuw den weg naar de nieuwe wereld te vinden. De oudste berichten evenwel aangaande reizen van Nederlanders naar de Nederlandsche Westindische gebieden van tegenwoordig dateeren van de laatste 15 jaar vóór 1600 .

$\mathrm{Zij}$ voeren naar de wilde of Indiaansche kust, waartoe ook Suriname behoorde, niet om te zoeken naar het land van El Dorado, of om aan de heidenen het Christendom te brengen, maar eenvoudig om wat ruilhandel te drijven met de schaarsche en weinig ontwikkelde Indianen.

En dat zij doordrongen in de Caraïbischen Zee - vóór den wind af - stond in verband met de behoefte aan zeezout, een artikel dat destijds een groote rol speelde, direct en indirect, voor den $\mathrm{Ne}$ derlandschen exporthandel; niet alleen dat haringvisscherij en zuivelindustrie, beide ook voor export werkende, zout noodig hadden, maar het product der Zeeuwsche en Hollandsche ziederijen was ook zelf een uitvoerartikel.

Dat zoutprobleem werd natuurlijk moeilijker toen in de laatste jaren der 16e eeuw het ernst scheen te zullen worden met het sluiten van de Spaansche en Portugeesche havens voor de schepen van Philip's rebelleerende onderdanen.

Dat wil zeggen de havens in Europa, want aan den overkant nam men het blijkbaar niet zoo nauw; hoe zou het anders mogelijk zijn geweest dat de Nederlanders zich van zeezout voorzagen aan 
de Oostkust van het tegenwoordige Venezuela, dicht bij het stadje Cumaná, de oudste vestiging der Spanjaarden op het vasteland van Amerika?

En van dat gedeelte van de kust naar de Benedenwindsche eilanden, ook al weder met den wind meê, was maar een stap, zoodat de zoutrijkdom ook van Bonaire, het meest Oostelijke van die eilanden, al vroeg bekend is geweest.

Zoeken wij naar stof tot vergelijkingen tusschen vroeger en nu, dan blijkt er geen gebrek te zijn aan beelden welke het verleden kunnen verbinden met het heden.

Wat in 1597 de natuurlijke gesteldheid van Suriname aanbood aan accommodatie voor de scheepvaart, dat is sedert niet veranderd en ook door menschenhanden niet noemenswaard verbeterd kunnen worden, wat meer zegt, het is steeds voldoende gebleven voor de behoeften. De breede en tamelijk diepe rivieren, uitmondende in den Atlantischen Oceaan, waren niet alleen voor Cabeliauw's notendopjes uitstekend bevaarbaar, maar zijn dat, rekening houdende met het getij, nog steeds in genoegzame mate voor middelgroote schepen van den tegenwoordigen tijd en aan meer bestond tot nu toe geen behoefte. De Suriname-rivier, ter hoogte van Paramaribo niet minder dan een K.M. breed, is door alle tijden de voor de scheepvaart meest belangrijke waterweg en havengelegenheid gebleven; de beperkte diepte der Surinaamsche rivieren en de afwezigheid van betere natuurlijke havens zou pas een bezwaar blijken wanneer, b.v. door het vinden van een exploiteerbaren aardolie-rijkdom, het vraagstuk van den afvoer van miljoenen tonnen 's jaars onder de oogen zou moeten worden gezien.

Nog op het einde der 18e eeuw waren de schepen welke op Suriname voeren gemiddeld niet grooter dan 200 ton en wanneer wij lezen van de geweldig drukke scheepvaart op Suriname in den bloeitijd, toen er wel eens dertig Hollandsche schepen tegelijk op de reede van Paramaribo geankerd lagen, dan moeten wij ook bedenken wat voor schepen dat waren.

De geheele jaarlijksche productie der plantages in de tweede helft der 18e eeuw zou met een zestal middelmatig groote vrachtbooten van tegenwoordig van uit Paramaribo kunnen worden verscheept en zelfs omstreeks 1860 was een bark van 450 ton al het grootste schip dat op de West voer.

Op onze Antillen zijn grootere verschillen tusschen voorheen en thans aan te wijzen dan in Suriname, zoowel gunstige veranderin- 
gen op bepaalde eilanden als ongunstige op andere, maar ook aldaar maakt men nog gebruik van de voordeelen, waarmede de natuur zelf ons uitnoodigend is tegemoet gekomen, voor zoover dan die voordeelen nog waarde voor ons hebben.

Het drie eeuwen oude Bonairiaansche zoutbedrijf wordt nog altijd voortgezet en een blik op de kaart maakt ons duidelijk dat Bonaire door de natuur als het ware tot een zouteiland is bestemd. Aan de lijzijde, zoowel in het Noorden als in het Zuiden, vinden wij z.g. pekelmeeren, ondiepe plassen vlak bij zee, die ideale zoutpannen vormen. Niet meer van beteekenis voor de overzeesche markten, vindt het zout tegenwoordig in den naasten omtrek toch nog afzet.

Anders is het gegaan met het verfhout, het kostbare campêche, dat een belangrijk deel uitmaakte van de door Piet Hein veroverde zilvervloot en dat men op Bonaire maar voor het kappen had, tot honderd jaar geleden. Dit product van Zuid- en CentraalAmerikaanschen- en Westindischen bodem heeft in onzen tijd van chemische kleurstoffen zijn beteekenis verloren en zou voor de huidige oceaanvaart geen loonende vracht meer opleveren, maar eertijds was het van belang voor de vaderlandsche textielnijverheid en onze wijze voorouders lieten het bewerken door de veroordeelden in de Amsterdamsche gevangenis, welke daaraan in den volksmond den naam van rasphuis dankte, of door de bemanningen der schepen die het vervoerden; ook tegenover de zeelieden sloeg men uit de bestrijding der verderfelijke ledigheid nog gaarne een voordeeltje bovendien.

De eigenlijke ontwikkeling van onze scheepvaart op de West vangt aan met de oprichting der West-Indische Compagnie, die een zeilend driemastschip in haar wapen voerde en die het hare heeft gedaan om ook in de nieuwe wereld een Nederlandsch Koloniaal rijk te stichten.

Van wat er in onze z.g. gouden eeuw in de Amerika's voor korter of langer tijd als Nederlandsch gebied heeft gegolden en meer of minder intensief is gekoloniseerd geworden, is thans niet anders overgebleven dan Suriname, toch nog een land ruim vijf maal zoo groot als Nederland - ongeveer even groot als Java - en zes kleine eilanden, waarvan echter Curaçao belangrijk is en Aruba op weg om belangrijk te worden; dat er niet meer over is behoeft ons noch te verwonderen, noch te bedroeven.

Wij kunnen het tegenwoordig slechts een begrijpelijken gang van zaken vinden dat aan ons 17e eeuwsche avontuur in Brazilië, een land maar betrekkelijk weinig minder groot dan geheel Euro- 


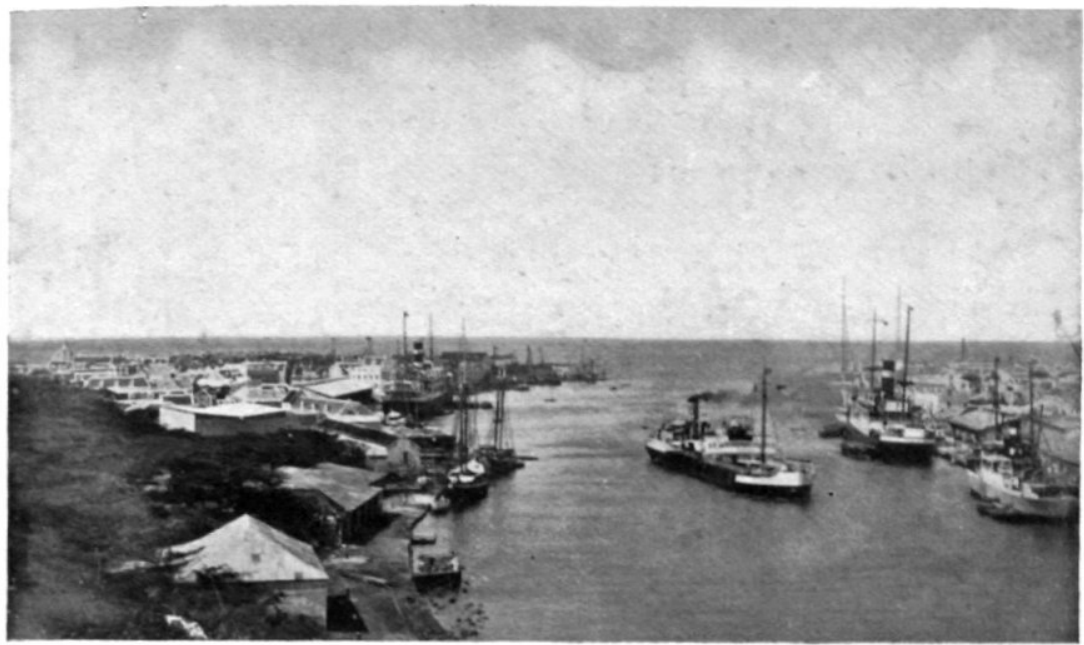

fig. I. Tankboot met een lading ruwe olie uit het Maraçaibogebied de havens van Curaçao binnenstoomende

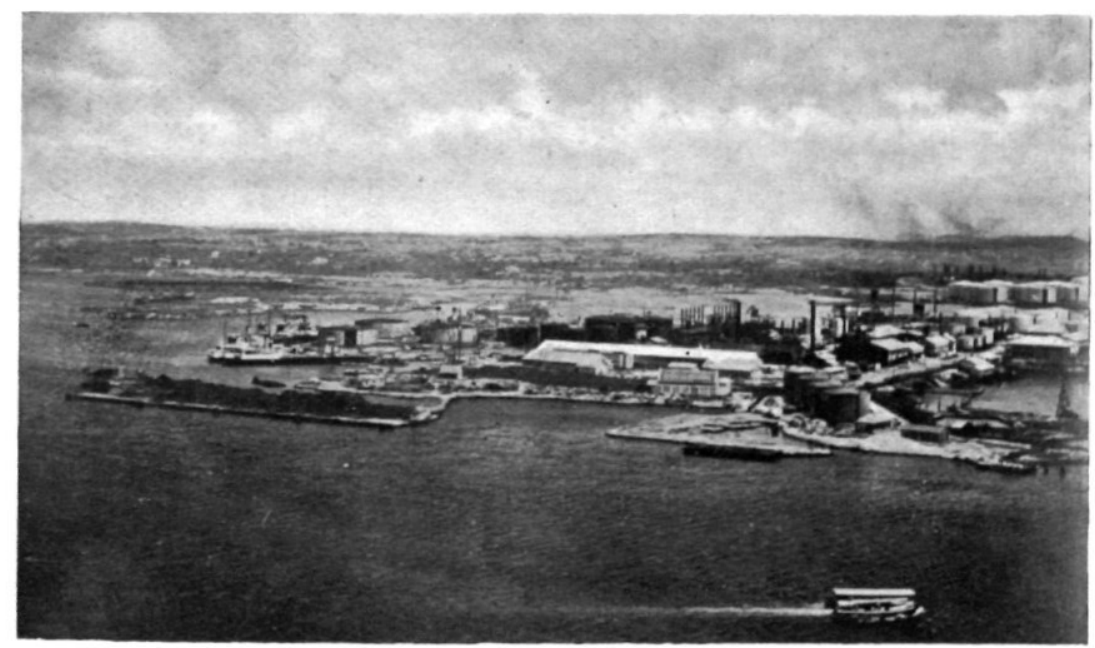

fig. 2. Petroleum-industrie op Curaçao: Etablissement in Schottegat; Westelijk deel 


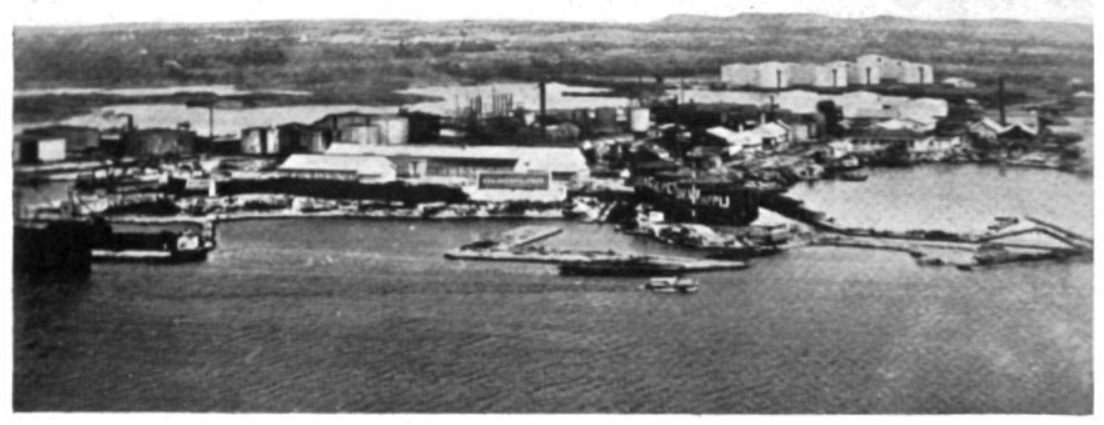

fig. 3. Petroleum-industrie op Curaçao.

Etablissement in het Schottegat; Middendeel

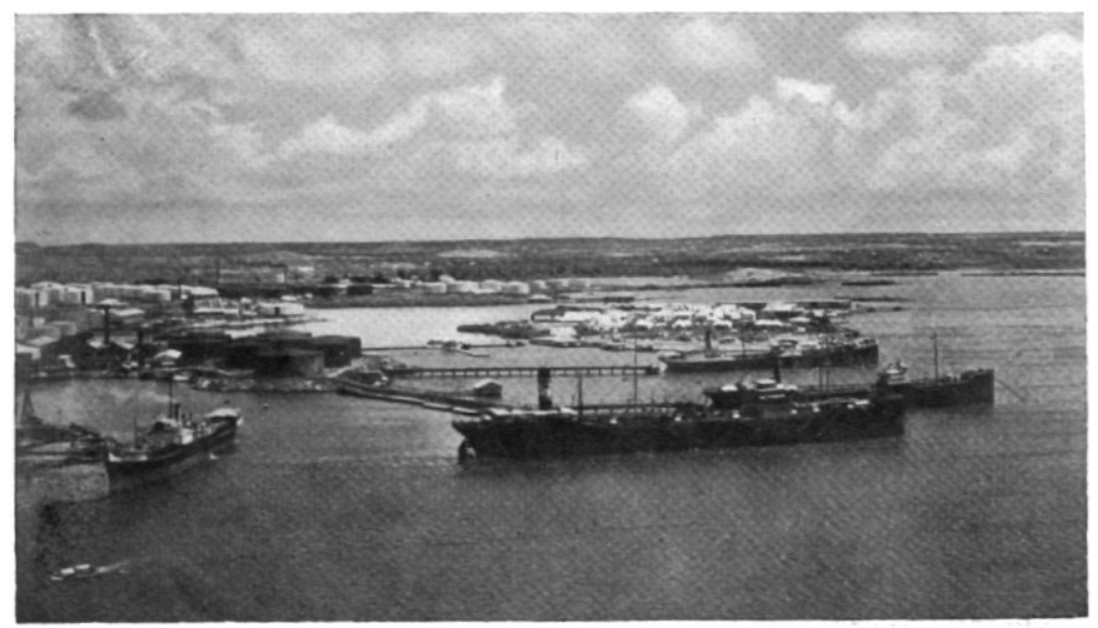

fig. 4. Petroleum-industrie op Curaçao.

Etablissement in het Schottegat; Oostelijk deel met groote tankschepen raffinaderij-producten ladende 


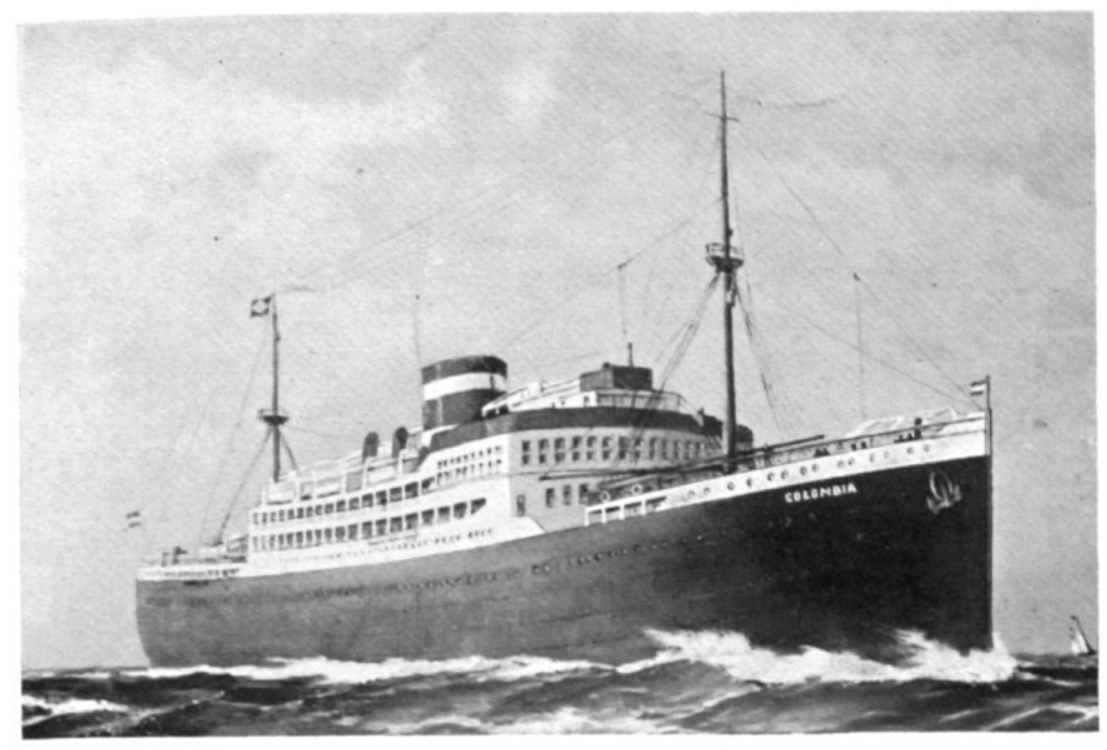

fig. 5. Dubbelschroefstoomschip „Colombia” van de Colonlijn

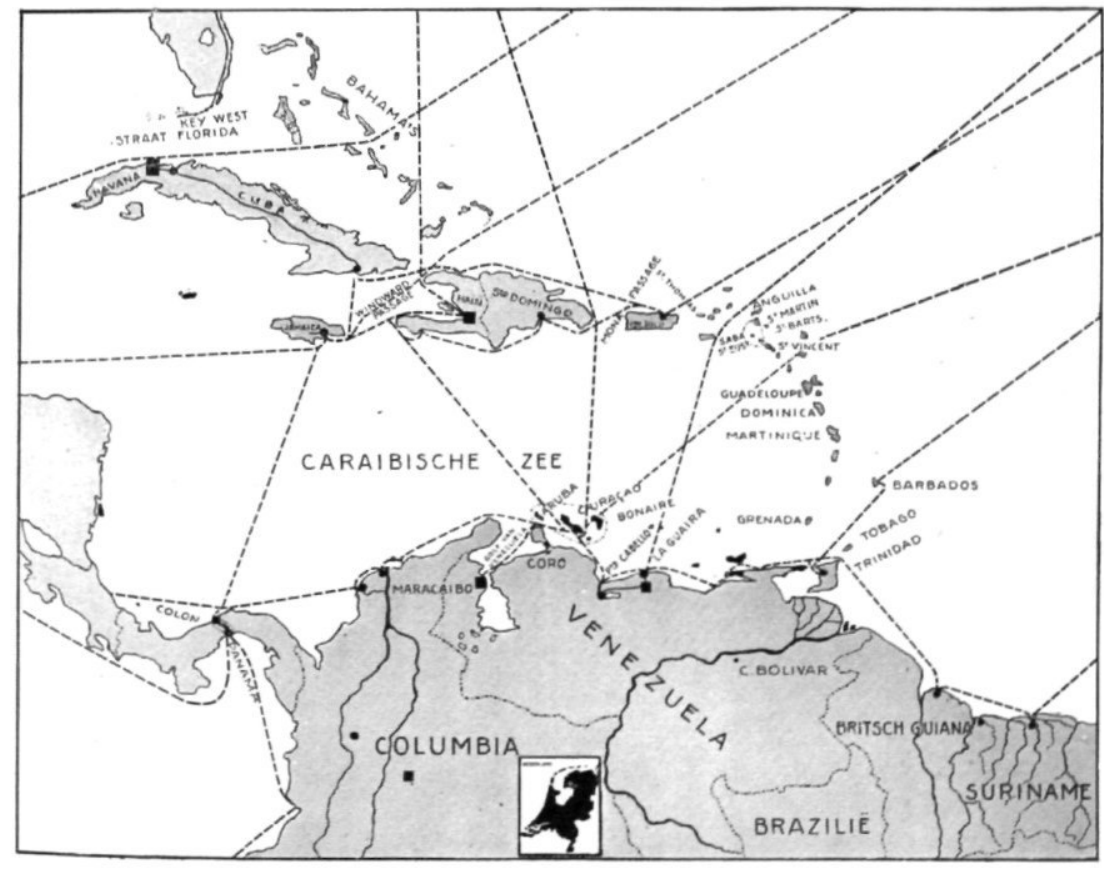

fig. 6. Overzichtskaartje der Nederlandsche Stoomvaartlijnen op en in West-Indië 
pa, spoedig een einde is gekomen en het huidige Britsch Guiana, samengesteld uit drie voormalige Nederlandsche koloniën is voor Engeland thans geen meer waardevol bezit dan Suriname voor ons is.

Eerder valt het te betreuren dat de pioniersarbeid in NoordAmerika verricht door de Nederlanders, alsmede hun bijna 150 jarige bedrijvigheid in Zuid-Afrika, geen blijvende resultaten hebben opgeleverd, zoodat ons volk geen enkel plekje buiten de zon heeft overgehouden, als expansiegebied in de gematigde luchtstreek, waarheen een bevolkingsoverschot zou kunnen emigreeren, zonder voor den Nederlandschen stam verloren te gaan.

Intusschen, het was in de 17e eeuw minder te doen om dit toekomstige belang, dan wel om het oogenblikkelijke van handel en scheepvaart en Suriname, omstreeks 1600 nog een soort niemandsland, waar enkele kleine factorijen waren ontstaan voor den ruilhandel met de Indianen en een enkele tabaksaanplanting was aangelegd, bleek bij uitstek geschikt om tropische landbouwgewassen voort te brengen voor de Europeesche markt.

Van die geschiktheld profiteerden aanvankelijk de Engelschen en de onder hun bestuur levende vreemdelingen, meest Joden; men voerde negerslaven in en beoefende met succes de suikercultuur.

Totdat in 1667 een Zeeuwsche vloot de Suriname-rivier opvoer en het fort vermeesterde bij Paramaribo, ruim 20 K.M. varens van af de monding, dat thans nog den naam Zeelandia draagt. Suriname werd daardoor Nederlandsch, d. w. z. eerst een Zeeuwsche kolonie, daarna exploitatiegebied eener vennootschap, de Geoctroyeerde Societeit van Suriname, met als deelhebbers de stad Amsterdam, de West-Indische Compagnie en de familie van den Gouverneur van Aerssen van Sommelsdijk.

Justitia, Pietas, Fides, zoo luidde het devies waaronder de societeit het bewind voerde - exploiteerde en bestuurde tegelijkertijd - het devies waaronder zooveel is geschied dat in onze oogen met de bewoordingen in den meest flagranten strijd was.

Haar wapenschild was een combinatie van het Amsterdamsche stadswapen, het scheepje van de Compagnie en het blazoen van het huis Sommelsdijk, met als schildhouders een Indiaan ter eene zijde, een Afrikaan ter andere. Die beide 17e eeuwsche schildhouders, de eene een vertegenwoordiger van de roode inheemsche menschensoort, de andere van het zwarte ras, in slavernij naar Suriname overgebracht om daar voor den plantagelandbouw de arbeidskracht te leveren, zij beiden geven alweder stof tot vergelijking tusschen voorheen en thans.

West Indische Gids XII

16 
De Indiaan is vrijwel gebleven wie hij was, de pogingen om hem slavenarbeid te laten verrichten zijn niet van langen duur geweest; hij is af en toe onze bondgenoot geweest, maar heeft zich aan onze beschaving zelfs nu nog niet aangepast.

Heel anders staat het met de niet-oorspronkelijke bewoners, de Afrikanen. Thans, 300 jaar na hun komst en een goede 60 jaar na de emancipatie, treft men in Suriname menschen aan bij de vleet van Afrikaansche bloedsmenging, meer of minder met blanken vermengd, die even goed onderwezen zijn en even Hollandsch in taal en manieren als wij.

Toch vindt ook die wilde Afrikaan van het embleem der societeit nog een pendant in een tegenwoordigen bewoner van Suriname, in den boschneger n.l. Ten getale van 17000 , ruim $11 \%$ der totale bevolking, leven nog langs de groote rivieren de afstammelingen der ontvluchte slaven, die in het oerwoud een onafhankelijk bestaan hebben gevonden.

Een der weinige lichtpunten van de slavernij is dat zij den Afrikaan in contact hebben gebracht met de Europeesche beschaving; deze boschnegers evenwel zijn zich aan dat contact blijven onttrekken; ook na de emancipatie. Zij vormen dus nu een soort anachronisme in de Surinaamsche samenleving en tevens een herinnering aan het weinig krachtige bewind in Suriname's bloeiperiode, een bewind dat niet wist te verhinderen dat wegloopers zich blijvend aan het gezag ontrokken.

(Wordt vervolgd). 